\title{
CORONAVIRUS COMPONENTS AND EXECUTION PHASE OF HIGHER EDUCATION AND INSTITUTIONAL ADVANCEMENT PROJECT IN RWANDA: A CASE OF UR-SWEDEN PROGRAMME FOR RESEARCH, HIGHER EDUCATION, AND INSTITUTIONAL ADVANCEMENT
}

\author{
Isimbi Edwige $^{1 *}$, Dr. Eugenia Nkechi Irechukwu ${ }^{2}$ \\ *1 Postgraduate student, School of Business and Economics, Mount Kenya University - Rwanda \\ ${ }^{2}$ Lecturer, School of Business and Economics, Mount Kenya University - Rwanda
}

*Corresponding Author: -

\begin{abstract}
: -
Project execution is a phase in which resources get allocated to deliver outcomes expected by stakeholders, while bringing to reality the vision of the project. Many projects often fail during execution phase due to failure to meet beneficiaries' needs, due to different knowns or unknowns. Coronavirus is one of the unknowns that might have affected projects' execution phase in one way or another. So, the main intention of this study is to determine the effect of coronavirus components on project execution phase: a case study of UR-Sweden programme for research, higher education, and institutional advancement. In this research, a census has been employed to collect quantitative data from respondents by use of Likert scale questionnaires. From 41 questionnaires distributed only 37 respondents filled them, representing a 90.2\% response rate. To analyze the quantitative data, a descriptive and inferential research design were done using SPSS version 20.0. From the findings, there is a negative correlation of -0.384 between lockdown and project execution phase, a negative correlation between physical distancing and project execution phase of -0.329 , and a negative correlation between curfew and project execution phase of -

0.301. From the multiple regression analysis, it was found that: a change in lockdown by one unit leads to 0.366 decrease in the project execution phase, a change in curfew by one unit leads to a 0.130 decrease in the project execution phase, and a unit change in physical distancing leads to a 0.489 decrease in the project execution phase. In addition, from the hypothesis testing done at a significance level of 5\%, it is clear that the relationship between lockdown and project execution phase is statistically significant, as well as the relationship between physical distancing and project execution phase. However, the relationship between curfew and project execution phase is not statistically significant.
\end{abstract}

Keywords: - Coronavirus pandemic, lockdown, curfew, physical distancing, project execution phase.

\section{(a) $(\$)$}




\section{INTRODUCTION}

Historically, countries worldwide have successfully dealt with serious pandemics like the 2009 Swine flu pandemic, the 1918 Spanish flu pandemic, etc., and different major epidemics like Smallpox, Influenza, Cholera, Yellow fever, Leprosy, Ebola, etc. The American Journal of Biomedical Sciences (AJBMS) noted that currently, the world is facing the coronavirus which is caused by infection with the SARS-CoV-2 virus strain (AJBMS, 2020), and whose vaccine has not yet been accessed by the majority of the world. For that reason, the best approach that was proposed by the World Health Organization (WHO) to stay safe is to be physically distant, wear a mask and wash hands or sanitize as much as possible (WHO, 2020).

For managers of project to lead their projects from initiation to termination with success, they design a sequence of phases that the project has to go through, namely, project conception phase, project planning, project execution, and project termination (Midori, 2019). Thus, projects have a definite start, end, and are constrained by time. According to Project Management Institute (PMI, 2008) many projects often fail in the execution stage. These projects even though they were well thought in the initiation stage, knowns or unknowns arise during the execution phase leading to failure of project implementation or calling for change in the initial plan. The arrival of the Coronavirus pandemic has also been one of those unknowns and has severely affected the normal way of living, affecting almost every sector and all activities, as the world was trying to curb the spread of the pandemic.

Therefore, this research aims at assessing coronavirus components and execution phase of higher education and institutional advancement projects in Rwanda: A case of UR-Sweden programme for research, higher education, and institutional advancement.

\subsection{Research objectives}

\subsubsection{General Objectives of the Study}

The general objective of this research is to determine the effect of coronavirus components on project execution phase: a case study of UR-Sweden programme for research, higher education, and institutional advancement.

\subsubsection{Specific Objectives of the Study}

i. To determine the effect of the lockdown on the project execution phase of the UR-Sweden programme for research, higher education, and institutional advancement.

ii. To assess the effect of the curfew on the project execution phase of the UR-Sweden programme for research, higher education, and institutional advancement.

iii. To establish the effect of physical distancing on the project execution phase of the UR-Sweden programme for research, higher education, and institutional advancement.

\section{Literature Review}

The COVID-19 pandemic caused serious consequences economically across the world, leading to changes in how businesses act. Changes were also realized in consumer behavior, and in aspects associated with staffs and managers, thus affecting the execution of many projects (Naveen \& Anders, 2020). Data from the Federal Statistical Office of Germany, DESTATIS, indicated that projects in Germany had above forty percent drop in revenue between March - August 2020 in comparing it to 2019, the same months. Results of a McKinsey Global Institute (MGI) survey, conducted in August 2020, on more than 2,200 SMEs projects in five European countries also shows how that their productivity had been affected by the Coronavirus.

In an interview with the Indian newspaper, Economic Times, Satish Magar, the president of CREDAI, said that over $30 \%$ employees were not managing to go to their workplaces due lockdown measures in their home places, causing most of the stations to run with about half of their usual employees (2020), thus delaying the implementation of many projects. In addition, according to Singh, Bandewar, and Bukusi (2020), in their Bulletin at the WHO, the nature of lockdown is very restrictive to the point that people are only being permitted to leave their households under some conditions. By April 2020, lockdowns were affecting around fifty-eight percent of the global population, and specifically $2.7 \mathrm{Bn}$ employees worldwide (eighty-one percent of the global labor force) (NCBI, 2020), which in turn affected the execution of many projects worldwide.

However, every cloud has a silver lining, despite the effects of lockdown on different sectors, total or partial lockdown has been of great role in fighting against Coronavirus pandemic. In summer, in Rwanda, a 21-days lockdown in Kigali city has reduced new cases by $72 \%$ as pointed out by the Rwanda Biomedical Center (2021). In Jordan, as per the research by Khatatbeh (2020), implementing a nationwide curfew, together with other interventions, has been operative in decreasing the percentage of new infections in the country. However, curfew measures have also negatively affected the execution of projects in different places. The International Labor Organization (ILO) estimated that due to curfew measures working hours globally has reduced by $17.3 \%$ and $23.3 \%$ in lower-middle income economies (ILO, 2020), which is evident that there has been a delay or other negative effects on the execution of different projects. In addition, in Bangladesh, 1 million workers have been stopped from their workplaces due to the undesirable termination of different projects (Antara, 2020).

From an assessment conducted on more than 5,800 small projects in the early days of Covid-19 pandemic, it was realized that mass dismissals from work had occurred by the time of the assessment, while other small projects were afraid that they will close doors once the pandemic continues for long, as they were financially unstable. All this was due to Covid-19 containment measures mainly curfew as it reduces number of work hours, where many 
people were seeking services by those projects (Bartik, Luca, \& Stanton, 2020). The execution of projects in nations with a big percentage of foreign employees, such as the Philippines, India, etc., have mostly been affected as curfew measures were not in favor of migrant workers and varied in different countries as it has been found by the Organization for Economic Co-operation and Development (OECD, 2020).

Miklós and Rita in their study Business disruptions from social distancing (2020), remarked that physical distancing measures are effective against pandemics but also harmful to the economy. They highlighted how projects that depend mostly on in-person communication to manufacture a product or give a service have been very affected, giving an example of the USA where 43 million workers worked in such places, and since then many of them lost their jobs. A report of a survey that was also carried out by PMI and the Project Business Foundation (2020) shows that COVID-19 has hit organizations on three management levels: project, contract, and business management. In the same way, due to physical distancing, $60.9 \%$ of businesses have seen their amount of work that was to be performed falling, losing over half their productions. There have also been changes to normal business processes to execute their projects for them to stop the spread of Covid-19 (Alekseev, Amer, Gopal, Kuchler, Schneider, Stroebel, \& Wernerfelt, 2020).

\section{Materials and Methods}

This research used the descriptive and inferential research design to analyze quantitative data using SPSS version 20.0. The choice of this design is suitable for this research as it specifically allows the researcher to extensively understand coronavirus components and project execution phase in Rwanda. This research had also collected qualitative data which was analysed using thematic analysis. The researcher emailed online questionnaires to 41 respondents who were benefiting from the program during the coronavirus pandemic, and 37 of them were completely filled.

The statistical measures have been used to summarize and classify research data into tables, percentages, mean, standard deviation, correlation, and regression analysis tables. The model of regression coefficient $\gamma=\beta_{0}+\beta_{1} X_{1}+$ $\beta_{2} X_{2}+\beta_{3} X_{3}+\varepsilon$ where $\gamma$ represents the dependent variable which is project execution phase, while $X_{1}, X_{2}$, and $X_{3}$ are lockdown, curfew, and physical distancing respectively. In addition, $\beta_{0}$ is the constant or intercept (which means that there may be other factors affecting project execution phase of our case study other than those under research), and $\beta_{1}, \beta_{2}, \beta_{3}$ are coefficients of the independent variable, and $\mathcal{E}$ is the error term.

\section{Results}

\subsection{Lockdown and project execution phase}

Table 4.1. Lockdown and project execution phase

\begin{tabular}{|c|c|c|c|c|c|c|c|c|}
\hline \multirow[t]{2}{*}{ Statement } & \multirow[t]{2}{*}{$\mathbf{N}$} & \multirow{2}{*}{$\begin{array}{l}\text { SA } \\
\%\end{array}$} & \multirow{2}{*}{$\begin{array}{l}\mathbf{A} \\
\%\end{array}$} & \multirow{2}{*}{$\begin{array}{l}\mathbf{N} \\
\%\end{array}$} & \multirow{2}{*}{$\begin{array}{l}\mathbf{D} \\
\%\end{array}$} & \multirow{2}{*}{$\begin{array}{l}\text { SD } \\
\%\end{array}$} & \multirow[t]{2}{*}{ Mean } & \multirow[t]{2}{*}{ Std. } \\
\hline & & & & & & & & \\
\hline $\begin{array}{l}\text { University/place of research was closed } \\
\text { during lockdown }\end{array}$ & 37 & 59.5 & 32.4 & 0.0 & 8.1 & 0.0 & 1.57 & .867 \\
\hline It was possible to continue your & & & & & & & & \\
\hline $\begin{array}{l}\text { research/studies even during lockdown } \\
\text { (e.g. online) }\end{array}$ & 37 & 16.2 & 40.5 & 8.1 & 21.6 & 13.5 & 3.24 & 1.342 \\
\hline $\begin{array}{l}\text { For studies/research done online, there was } \\
\text { no disruption caused by internet connection }\end{array}$ & 37 & 0.0 & 5.4 & 0.0 & 40.5 & 54.1 & 1.57 & .765 \\
\hline $\begin{array}{l}\text { The initial plan of studies or research has } \\
\text { been modified due to lockdown }\end{array}$ & 37 & 16.2 & 37.8 & 5.4 & 18.9 & 21.6 & 3.08 & 1.460 \\
\hline $\begin{array}{l}\text { Unexpected lockdowns affected the } \\
\text { implementation plan of the project }\end{array}$ & 37 & 37.8 & 27.0 & 13.5 & 5.4 & 16.2 & 3.65 & 1.457 \\
\hline Valid N (listwise) & 37 & & & & & & & \\
\hline
\end{tabular}

Source: Researcher, 2021

From the collected data, 59.5 percent strongly agreed that their universities were closed during lockdown, 32.4 percent agreed, while 8.1 percent disagreed with the statement. 40.5 percent of respondents agreed that they have been able to continue their research/studies even during the lockdown (e.g., online), 21.6 percent disagreed, 16.2 percent strongly agreed, 13.5 percent strongly disagreed, and 8.1 percent were neutral with the statement. In addition, 54.1 percent strongly disagreed that there was no disruption caused by internet connection, 40.5 percent of them disagreed, while 5.4 percent agreed. Furthermore, 37.8 percent agreed that the initial plan of research and studies has been modified due to lockdown, 21.6 percent strongly disagreed, 18.9 percent disagreed, 16.2 percent were strongly agreed, while 5.4 percent were neutral with the statement. On the implementation plan, majority 
37.8 percent of the respondents strongly agreed that unexpected lockdowns affected the implementation plan of the programme, 27.0 percent agreed, 16.2 percent strongly disagreed, 13.5 were neutral, while 5.4 percent disagreed with the statement.

\subsection{Curfew and project execution phase}

Table 4.2 Curfew and project execution phase

\begin{tabular}{|c|c|c|c|c|c|c|c|c|}
\hline Statement & $\mathbf{N}$ & $\begin{array}{l}\text { SA } \\
\%\end{array}$ & $\begin{array}{l}\mathbf{A} \\
\%\end{array}$ & $\begin{array}{l}\mathbf{N} \\
\%\end{array}$ & $\begin{array}{l}\text { D } \\
\%\end{array}$ & $\begin{array}{l}\text { SD } \\
\%\end{array}$ & Mean & Std. \\
\hline $\begin{array}{l}\text { Before the pandemic there was classes or } \\
\text { researches scheduled to start after } 6 \mathrm{pm}\end{array}$ & 37 & 8.1 & 56.8 & 0.0 & 24.3 & 10.8 & 3.27 & 1.239 \\
\hline $\begin{array}{l}\text { Classes/researches were shifted to hours before } \\
\text { the curfew }\end{array}$ & 37 & 35.1 & 45.9 & 0.0 & 13.5 & 5.4 & 2.08 & 1.187 \\
\hline $\begin{array}{l}\text { There were technologies adopted to continue } \\
\text { classes/researches even after the curfew, at } \\
\text { home }\end{array}$ & 37 & 51.4 & 29.7 & 8.1 & 8.1 & 2.7 & 1.81 & 1.076 \\
\hline $\begin{array}{l}\text { The curfew has disrupted you from going to } \\
\text { field or to continue your research }\end{array}$ & 37 & 48.6 & 21.6 & 10.8 & 8.1 & 10.8 & 2.11 & 1.390 \\
\hline $\begin{array}{l}\text { Curfew reduced studying/research hours, then } \\
\text { there is probability that the current } \\
\text { implementation phase will be extended }\end{array}$ & 37 & 2.7 & 16.2 & 29.7 & 40.5 & 10.8 & 2.59 & .985 \\
\hline Valid N (listwise) & 37 & & & & & & & \\
\hline
\end{tabular}

Source: Researcher, 2021

Collected data show that 56.8 percent of respondents agreed that before the pandemic, there were classes or researches that were scheduled to start after $6 \mathrm{pm}, 24.3$ percent disagreed, 10.8 percent strongly disagreed, while 8.1 percent strongly agreed. On the next statement, 45.9 percent of the respondents agreed that classes/researches were shifted to hours before the curfew, 35.1 percent strongly agreed, 13.5 percent disagreed, and 5.4 percent strongly disagreed with the statement.

In addition, 51.4 percent strongly agreed that there are technologies they adopted to continue classes or researches even after curfew at home, 29.7 percent agreed, 8.1 percent were neutral, 8.1 percent disagreed, while 2.7 percent strongly disagreed with the statement. Furthermore, 48.6 percent strongly agreed that curfew disrupted them from going to field or to continue their researches, 21.6 percent agreed, 10.8 percent were neutral, 10.8 strongly disagreed, while 8.1 percent disagreed. Moreover, majority 40.5 percent disagreed that there is probability that the current execution phase will be extended, 29.7 percent were neutral, 16.2 percent agreed, 10.8 percent strongly disagreed, while 2.7 percent strongly agreed with the statement.

\subsection{Physical distancing and project execution phase}

Table 4.3. Physical distancing and project execution phase statement

\begin{tabular}{|c|c|c|c|c|c|c|c|c|}
\hline Statement & $\mathbf{N}$ & $\begin{array}{c}\text { SA } \\
\%\end{array}$ & $\begin{array}{l}\mathbf{A} \\
\%\end{array}$ & $\begin{array}{l}\mathrm{N} \\
\%\end{array}$ & $\begin{array}{l}\mathrm{D} \\
\%\end{array}$ & $\begin{array}{c}\text { SD } \\
\%\end{array}$ & Mean & Std. \\
\hline $\begin{array}{l}\text { There are technologies adopted to } \\
\text { facilitate you to study/do your } \\
\text { research from different locations due } \\
\text { to physical distancing }\end{array}$ & 37 & 45.9 & 32.4 & 2.7 & 16.2 & 2.7 & 1.97 & 1.190 \\
\hline $\begin{array}{l}\text { As a researcher/student you remained } \\
\text { fully productive while working from } \\
\text { home, as you were before the } \\
\text { pandemic }\end{array}$ & 37 & 35.1 & 16.2 & 2.7 & 2.7 & 43.2 & 2.05 & 1.079 \\
\hline $\begin{array}{l}\text { Studies/researches continued } \\
\text { observing physical distancing } \\
\text { measures (e.g., using big rooms) }\end{array}$ & 37 & 13.5 & 62.2 & 16.2 & 5.4 & 2.7 & 2.22 & .854 \\
\hline $\begin{array}{l}\text { The quality of education/research } \\
\text { was not affected by the physical } \\
\text { distancing measures }\end{array}$ & 37 & 2.7 & 35.1 & 0.0 & 45.9 & 16.2 & 2.62 & 1.210 \\
\hline $\begin{array}{l}\text { You were afraid of getting } \\
\text { coronavirus when universities re- } \\
\text { opened }\end{array}$ & 37 & 64.9 & 29.7 & 2.7 & 0.0 & 2.7 & 1.78 & 630 \\
\hline Valid N (listwise) & 37 & & & & & & & \\
\hline
\end{tabular}

Source: Researcher, 2021

Data collected show that 45.9 percent strongly agreed that there are technologies adopted to facilitate them to study/do their researches from different locations (at home) due to physical distancing, 32.4 percent agreed, 16.2 percent disagreed while 2.7 percent strongly disagreed, and 2.7 percent were neutral on this statement. On remaining fully productive while working from home as they were before the pandemic, 43.2 percent strongly disagreed, 35.1 strongly agreed, 16.2 agreed, 2.7 were neutral and 2.7 disagreed with the statement. In addition, most 62.2 percent of the respondents agreed that their studies or researches continued even with physical distancing (using big rooms), 16.2 percent were neutral, 13.5 percent strongly agreed, 5.4 percent disagreed, while 
2.7 percent strongly disagreed. Furthermore, 45.9 percent disagreed that the quality of education was not affected by the physical distancing measures, 35.1 percent agreed, 16.2 percent strongly disagreed, while 2.7 percent strongly agreed. On fears of contracting the pandemic, majority 64.9 percent strongly agreed that they were afraid of getting coronavirus when universities were re-opened, 29.7 percent agreed, while 2.7 percent strongly disagreed, and 2.7 percent were neutral on this statement.

\subsection{Project execution phase}

\section{Table 4.4. Project execution phase}

\begin{tabular}{|c|c|c|c|c|c|c|c|c|}
\hline Statement & $\mathrm{N}$ & $\begin{array}{l}\text { SA } \\
\%\end{array}$ & $\begin{array}{l}\mathbf{A} \\
\%\end{array}$ & $\begin{array}{l}\mathbf{N} \\
\%\end{array}$ & $\begin{array}{l}\text { D } \\
\%\end{array}$ & $\begin{array}{l}\text { SD } \\
\%\end{array}$ & Mean & Std. \\
\hline $\begin{array}{l}\text { Your study/research grant } \\
\text { was not in any way disrupted } \\
\text { by the pandemic }\end{array}$ & 37 & 5.4 & 21.6 & 0.0 & 24.3 & 48.6 & 2.16 & 1.405 \\
\hline $\begin{array}{l}\text { Coronavirus caused no } \\
\text { variance between the cost } \\
\text { planned for your } \\
\text { research/studies and the cost } \\
\text { you have incurred so far }\end{array}$ & 37 & 10.8 & 5.4 & 24.3 & 13.5 & 45.9 & 2.30 & 1.450 \\
\hline $\begin{array}{l}\text { There are measures taken that } \\
\text { will allow the current phase } \\
\text { of the project to be completed } \\
\text { with the period set for } \\
\text { completion }\end{array}$ & 37 & 5.4 & 21.6 & 51.4 & 18.9 & 2.7 & 4.00 & 1.269 \\
\hline $\begin{array}{l}\text { The quality of } \\
\text { research/studies has not been } \\
\text { compromised during the } \\
\text { pandemic }\end{array}$ & 37 & 24.3 & 54.1 & 2.7 & 13.5 & 5.4 & 3.78 & 1.134 \\
\hline $\begin{array}{l}\text { The scope of the project has } \\
\text { not been affected }\end{array}$ & 37 & 8.1 & 13.5 & 64.9 & 13.5 & 0.0 & 3.16 & .764 \\
\hline Valid N (listwise) & 37 & & & & & & & \\
\hline
\end{tabular}

Source: Researcher, 2021

From the findings, 48.6 percent strongly disagreed with the statement that their research/study grants were not in any way affected by the pandemic, 24.3 disagreed, 21.6 agreed, while 5.4 strongly agreed. On the next statement, 45.9 percent of respondents strongly disagreed that the pandemic caused no variance with between the cost they had planned for their researches/studies and the cost incurred so far, 13.5 percent disagreed, 10.8 percent strongly agreed, 5.4 percent agreed while 24.3 percent were neutral. In addition, 51.4 percent were neutral with whether there are measures taken that will allow the current phase of the project to be completed within the set period of completion, 21.6 percent agreed, 18.9 percent disagreed, 5.4 percent strongly agreed while 2.7 strongly disagreed. Furthermore, 54.1 percent agreed that the quality of research or education has not been affected by the pandemic, 24.3 percent strongly agreed, 13.5 percent disagreed, 5.4 percent strongly disagreed, while 2.7 percent were neutral on this statement. Last but not least, 64.9 percent of respondents were neutral on the statement that the scope of the project has not been affected by the pandemic, 13.5 percent agreed, 13.5 percent disagreed, while 8.1 percent strongly agreed.

\subsection{Normality tests for all variables}

Testing whether data are normally distributed is needed mostly for parametric statistical analysis (Razali \& Wah, 2011). The parametric statistical analysis assumes the normal distribution and if this assumption is not respected, findings 'explanation can be invalid. The Shapiro-Wilk test is proposed by more researchers as the best tool for assessing data normality (Ghasemi \& Zahediasi, 2012). Given:

H0: Data is distributed normally H1: Data is not distributed normally

Table 4.5. below shows the findings of normality test.

Table 4.5. Tests of Normality

\begin{tabular}{lllllll}
\hline & \multicolumn{2}{l}{ Kolmogorov-Smirnov $^{\mathrm{a}}$} & \multicolumn{3}{l}{ Shapiro-Wilk } \\
& Statistic & $\mathrm{df}$ & Sig. & Statistic & df & Sig. \\
\hline Project execution phase & .962 & 37 & .010 & .094 & 37 & .051 \\
Lockdown & .138 & 37 & .074 & .944 & 37 & .060 \\
Physical distancing & .116 & 37 & $.200^{*}$ & .981 & 37 & .751 \\
Curfew & .171 & 37 & .008 & .958 & 37 & .171 \\
\hline
\end{tabular}

*. This is a lower bound of the true significance.

Source: Researcher, 2021 
All the four variables have Sig-values of Shapiro Wilk greater than 0.05 indicating that the test fails to reject the null hypothesis. The data collected is distributed normally, so the Pearson's correlation can be used.

4.6.Pearson's correlation analysis Table 4.6 Pearson's correlation analysis

\begin{tabular}{|c|c|c|c|c|c|}
\hline & & $\begin{array}{l}\text { Project execution } \\
\text { phase }\end{array}$ & Lockdown & Curfew & $\begin{array}{l}\text { Physical } \\
\text { distancing }\end{array}$ \\
\hline \multirow{4}{*}{$\begin{array}{l}\text { Project } \\
\text { execution } \\
\text { phase }\end{array}$} & Pearson Correlation & 1 & $-.384^{*}$ & -.301 & $-.329^{*}$ \\
\hline & Sig. (2-tailed) & & .019 & .071 & .047 \\
\hline & $\mathrm{N}$ & 37 & 37 & 37 & 37 \\
\hline & Pearson Correlation & $-.384^{*}$ & 1 & .247 & -.065 \\
\hline \multirow[t]{3}{*}{ Lockdown } & Sig. (2-tailed) & .019 & & .140 & .704 \\
\hline & $\mathrm{N}$ & 37 & 37 & 37 & 37 \\
\hline & Pearson Correlation & -.301 & .247 & 1 & .297 \\
\hline \multirow[t]{2}{*}{ Curfew } & Sig. (2-tailed) & .071 & .140 & & .74 \\
\hline & $\mathrm{N}$ & 37 & 37 & 37 & 37 \\
\hline \multirow{3}{*}{$\begin{array}{l}\text { Physical } \\
\text { distancing }\end{array}$} & Pearson Correlation & $-.329^{*}$ & -.0 .65 & .297 & 1 \\
\hline & Sig. (2-tailed) & .047 & .704 & .074 & \\
\hline & $\mathrm{N}$ & 37 & 37 & 37 & 37 \\
\hline
\end{tabular}

*. Correlation is significant at the 0.05 level (2-tailed).

Source: Researcher, 2021

The results in Table 4.6 indicate that there is a negative correlation between lockdown and project execution phase as shown by a value of -0.384 , value -0.301 indicate the correlation between curfew and project execution phase, and there is also a negative correlation between physical distancing and project execution phase of -0.329 . This means that as three independent variables increase the project execution decreases and vice versa.

\subsection{Multiple regression analysis}

Table 4.7 Regression Analysis

\begin{tabular}{|c|c|c|c|c|c|c|c|c|}
\hline \multicolumn{9}{|c|}{ Coefficients $^{\mathrm{a}}$} \\
\hline \multicolumn{2}{|c|}{ Model } & \multicolumn{2}{|c|}{$\begin{array}{l}\text { Unstandardized } \\
\text { Coefficients }\end{array}$} & \multirow{2}{*}{$\begin{array}{l}\text { Standardized } \\
\text { Coefficients } \\
\text { Beta }\end{array}$} & \multirow[t]{2}{*}{$\mathrm{t}$} & \multirow[t]{2}{*}{ Sig. } & \multicolumn{2}{|c|}{$\begin{array}{l}95.0 \% \text { Confidence Interval } \\
\text { for B }\end{array}$} \\
\hline & & $\mathrm{B}$ & Std. Error & & & & $\begin{array}{l}\text { Lower } \\
\text { Bound }\end{array}$ & Upper Bound \\
\hline \multirow{4}{*}{1} & (Constant) & 5.389 & .659 & & 8.172 & .000 & 4.047 & 6.730 \\
\hline & Lockdown & -.366 & .149 & -.377 & -2.453 & .020 & -.669 & -.062 \\
\hline & Curfew & -.130 & .186 & -.112 & -.699 & .489 & -.508 & .248 \\
\hline & $\begin{array}{l}\text { Physical } \\
\text { distancing }\end{array}$ & -.489 & .238 & -.320 & -2.050 & .048 & -.973 & -.004 \\
\hline
\end{tabular}

a. Dependent Variable: Project execution phase

Source: Researcher, 2021

Now, the equation $y=\beta 0+\beta 1 X 1+\beta 2 X 2+\beta 3 X 3+\varepsilon$ becomes: $y=\mathbf{5 . 3 8 9}-\mathbf{0 . 3 6 6} X_{1} \quad-\mathbf{0 . 1 3 0} X_{2}-\mathbf{0 . 4 8 9}_{3}$ Where:

$\mathrm{y}=$ Project execution phase (outcome or dependent variable)

$\mathrm{X}_{1}=$ Lockdown

$\mathrm{X}_{2}=$ curfew

$\mathrm{X}_{3}=$ Physical distancing

$\boldsymbol{\varepsilon}=$ Error term

Based on findings, it is demonstrated that taking lockdown, curfew, and physical distancing constant at zero, success of project execution phase will be 5.389 .

In addition, taking curfew and physical distancing at zero; an increase in lockdown by one unit leads to 0.366 decrease in the project execution phase, a change in curfew by one unit leads to 0.130 decrease in the project execution phase, and an increase in physical distancing by one unit leads to 0.489 decrease in the project execution phase.

\section{Discussion}

This part of the study dealt with the discussion of findings, the results of the study have shown that many beneficiaries this programme $(59.5 \%)$ have also been affected by the common issue brought by lockdown that their universities or places of researches were closed due to lockdown affecting most of them not to be able to continue their researches or studies. According to the World Bank (2020), the global school closures and the closure of different places caused by lockdown could lead to a loss of about 10 trillion US dollars in lifetime income for this generation. From the findings also, beneficiaries that tried to continue their activities using internet were disrupted by the poor internet connection (54.1\%). Such findings, according to the World Bank (2020) may possibly give the necessary encouragement to provide all-inclusive internet connection, since lockdown measures 
have shown how vital it is for everyone to access to reliable internet. In addition, most of beneficiaries (37.8\%) have been obliged to change their initial plans of studies or researches due to lockdown. The Global Environment Facility (2020) had also noted that projects under execution phase especially those whose activities involves field work, community engagement in remote areas, etc. have been severely affected, forced to delay, or to stop.

Correlation results indicated that lockdown has a negative correlation with project execution phase of -0.384 , which means that as lockdown was increasing the project execution phase was decreasing. In addition to that, regression findings indicated that lockdown has a statistically significant effect on project execution phase as denoted by $\rho$ of 0.020 . The study hence agrees with the literature that lockdown led to sudden shut down of projects and delays of others (Yaser \& Abdulsalam, 2020).

Talking about curfew, from the findings it can be noted that before the pandemic, the majority of beneficiaries $(56.8 \%)$ used to have classes or even research after $6 \mathrm{pm}$. Most of them (48.6\%) has been disrupted by the curfew to go on field to collect their data. The International Labor Organization had also estimated in its recent study that due to curfew measures working hours globally has reduced by $17.3 \%$ and $23.3 \%$ in lower-middle income countries like Rwanda (ILO, 2020). Using Pearson's correlation, it was found that there is a negative correlation between curfew and project execution phase as denoted by the value -0.301 , which means that as curfew measures increases, project execution phase decreases and vice versa. This supports what was reviewed in the literature in a study by Bartik, \& al., (2020) that included 5,800 projects which all agreed that due to curfew they are financially unstable and finds closing doors as an option if the pandemic continues. However, the regression analysis at 5\% significance level shows that there is no statistically significant relationship between curfew and project execution phase since the $\rho$ value is 0.489 which is greater than 0.05 .

Last but not least, findings related to physical distancing showed that the majority (45.9\%) disagreed that the quality of education or research was not affected by the physical distancing measures. $62.2 \%$ of respondents agreed that studies, trainings, and researches continued while observing physical distancing measures. Furthermore, $43.2 \%$ strongly disagreed that they remained fully productive while working from different locations. With Pearson's correlation, it was realized that there is a negative correlation between physical distancing and project execution phase as shows the value -0.329 . There is also a statistically significant relationship between physical distancing and project execution phase as shown by the $\rho$ value of 0.048 at $5 \%$ significance level. This confirms what was found by other researchers that while physical distancing can reduce the death toll of the pandemic, it imposes large costs on projects (Sachs, 2020), and as a result, projects continued to see the amount of work that was to be performed falling, losing over half the projects' expected outcomes (Alekseev \& al., 2020).

\section{Conclusions}

This study concludes that while lockdown measures are good to save lives in periods of pandemics, disasters, etc. it is also important to note that they have serious effects on other aspects of life like the project execution phase. The findings show that researchers and students could barely continue their studies and researches during lockdown, others could not rely on their internet connection which was poor and were in one way or another forced by the pandemic to change their initial research or study plans. All these clearly indicate that the lockdown had an effect on a project execution phase of the UR-Sweden programme for research, higher education, and institutional advancement.

It also concludes that curfew had no statistically significant effect on the project execution phase of the URSweden programme for research, higher education, and institutional advancement. This is due to the fact that even though curfew caused a reduction in the hours for research and studies and disrupted many of the beneficiaries from going to field, they still managed to make good use of technology, good internet availed to them at UR where the project works at and use the time before the curfew for their activities. The study can thus conclude that from the findings the curfew had an effect on the project execution phase at UR-Sweden programme for research, higher education, and institutional advancement, but which is not statistically significant.

This research also concludes that even though physical distancing measures reduced the number of those who can meet physically, researchers and students under this programme with the facilitation of the programme managed to continue their studies using big rooms, others adopted a specific technology to continue their researches and studies. However, according to them these measures might have affected the expected outcome of this project during this pandemic. With this, the findings of this study show that even though they've managed the effect of physical distancing on the execution phase of the project as much as they could, it still caused significant effect on the project execution phase of the UR-Sweden programme for research, higher education, and institutional advancement.

\section{Acknowledgement}

I thank God for providing all that was required to finish this program and strengthening me during some of the most difficult times. I am also grateful to my family and friends for their huge support.

To my supervisor Dr. Eugenia Nkechi Irechukwu thank you for your support, for editing my many mistakes, and making sure that my research project is always on track. I am also grateful to thank Mount Kenya University Rwanda forgiving the knowledge I needed to obtain my Masters' degree. Last but not least, I would also like to thank the UR-Sweden programme for research, higher education, and institutional advancement for their huge support in my data collection process. 


\section{References}

[1].Alekseev, G, Amer, S, Gopal, M, Kuchler, T, Schneider, J, Stroebel, J. \& Wernerfelt, N. (2020). The Effects of COVID-19 on U.S. small businesses: Evidence from owners, managers, and employees. London, Centre for Economic Policy Research.

[2].Antara, J. (2020). The impact of covid-19 on workers and businesses at the bottom of global garment supply chains.

[3].Bartik, A. W., Bertrand, M., Cullen, Z., Glaeser, E. L., Luca, M., \& Stanton, C. (2020). The impact of COVID19 on small business outcomes and expectations. Proceedings of the National Academy of Sciences of the United States of America, 117(30).

[4].Diop., M. (2020). What can AI tell us about COVID-19's impact on infrastructure? World Bank Blogs. Published. Ghasemi, A., \& Zahediasl, S. (2012). Normality Tests for Statistical Analysis: A Guide for NonStatisticians.

[5].International Journal of Endocrinology and Metabolism, 10, 486-489. 10.5812/ijem.3505.

[6].International Labor Organization. (2020). COVID-19 and the world of work: Updated estimates and analysis ( $2^{\text {nd }}$ edition). Geneva, International Labor Organization.

[7].Khatatbeh, M. (2020). Efficacy of Nationwide Curfew to Encounter Spread of COVID-19: A Case from Jordan. Frontiers in public health, 8(394).

[8].Melchor, A. S., Miguel, A. T., Frydman, T. D., \& Antonio, A. S. (2020). Social and Technological Innovation in Chronic Illness Management during the COVID-19 Pandemic. American Journal of Biomedical Science and Research, 10(5). 10.34297/AJBSR.2020.10.001564.

[9].Midori. N. (2019). The 4 Project Life Cycle Phases. Venngage.

[10]. Miklós., K. \& Rita, P., (2020). Business disruptions from social distancing.

[11]. Naveen, D. \& Anders, G. (2020). Effects of COVID-19 on business and research. Journal of Business Research, 117.

[12]. Organisation for Economic Co-operation and Development. (2020). Labor migration in Asia: Impacts of the covid-19 crisis and the post-pandemic future.

[13]. Project Management Institute \& Project Business Foundation (2020). The Impact of the COVID-19 Crisis on Project Business. Cooperative Survey of Project Management Institute and the Project Business Foundation. PMI White Papers.

[14]. Razali, N. M. \& Wah, B. Y. (2011). Power Comparisons of Shapiro-Wilk, Kolmogorov-Smirnov, Lilliefors, and Anderson-Darling Tests. J. Stat. Model. Analytics 2.

[15]. Rwanda Biomedical Center. (2021). Get the facts About Coronavirus.

[16]. Singh, J. A., Bandewar, S. V., \& Bukusi, E. A. (2020). The impact of the COVID-19 pandemic response on other health research. Bulletin of the WHO, 98(9).

[17]. The Economic times (2020). What a coronavirus lockdown looks likes, and what you can do \& what you can't. The Economic Times.

[18]. World Bank. (2020). Learning Losses due to COVID19 could add up to $\$ 10$ trillion. World Bank Group Publications.

[19]. World Bank. (2020). The effect of Covid-19 lockdown measures on internet speed: An empirical analysis of 18 countries in Africa.

[20]. Yaser, G. \& Abdulsalam, A. (2020). The Impact of Pandemic Crisis on the Survival of Construction Industry: A Case of COVID-19. Richtmann Publishing, 11(4). 